Zimmerli, Allegretti et al

\title{
1 Nuclear pores constrict upon energy
}

\section{2 depletion}

3

4

5 Christian E. Zimmerli*1,2,5, Matteo Allegretti*1, Vasileios Rantos ${ }^{3,4}$, Sara K. Goetz ${ }^{1,2}$, Agnieszka

6 Obarska-Kosinska $^{4,6}$, levgeniia Zagoriy ${ }^{1}$, Aliaksandr Halavatyi ${ }^{5}$, Julia Mahamid ${ }^{1}$, Jan

7 Kosinski ${ }^{1,3,4}$ and Martin Beck ${ }^{1,6}$

8

$9 *$ Contributed equally

10

11

Correspondence to jan.kosinski@embl.de or martin.beck@biophys.mpg.de

Affiliations:

141 Structural and Computational Biology Unit, European Molecular Biology Laboratory,

15 Meyerhofstraße 1, 69117, Heidelberg, Germany

162 Collaboration for joint PhD degree between EMBL and Heidelberg University, Faculty of

17 Biosciences

183 Centre for Structural Systems Biology (CSSB), Notkestraße 85, 22607, Hamburg, Germany

194 European Molecular Biology Laboratory Hamburg, Notkestraße 85, 22607, Hamburg,

20 Germany

215 Advanced Light Microscopy Facility, European Molecular Biology Laboratory, 22 Meyerhofstraße 1, 69117, Heidelberg, Germany

236 Department of Molecular Sociology, Max Planck Institute of Biophysics, Max-von-Laue-

24 Straße 3, 60438 Frankfurt am Main

25

26 Keywords: nuclear pore complex, cryo-FIB milling, cryo-electron tomography, nuclear

27 transport 
Zimmerli, Allegretti et al

\section{Abstract}

30 Nuclear pore complexes (NPCs) fuse the inner and outer nuclear membranes and mediate

31 nucleocytoplasmic exchange. They are made of 30 different nucleoporins that form an

32 intricate cylindrical architecture around an aqueous central channel. This architecture is

33 highly dynamic in space and time. Variations in NPC diameter were reported, but the

34 physiological circumstances and the molecular details remain unknown. Here we combined

35 cryo-electron tomography and subtomogram averaging with integrative structural modeling

36 to capture a molecular movie of the respective large-scale conformational changes in cellulo.

37 While actively transporting NPCs adopt a dilated conformation, they strongly constrict upon

38 cellular energy depletion. Fluorescence recovery after photo bleaching experiments show

39 that NPC constriction is concomitant with reduced diffusion and active transport across the

40 nuclear envelope. Our data point to a model where the energy status of cells is linked to the

41 conformation of NPC architecture. 
bioRxiv preprint doi: https://doi.org/10.1101/2020.07.30.228585; this version posted July 31, 2020. The copyright holder for this preprint (which was not certified by peer review) is the author/funder, who has granted bioRxiv a license to display the preprint in perpetuity. It is made available under aCC-BY-NC-ND 4.0 International license.

Zimmerli, Allegretti et al

\section{Introduction}

43 Nuclear pore complexes (NPCs) bridge the nuclear envelope (NE) and facilitate 44 nucleocytoplasmic transport. Across the eukaryotic kingdom, about 30 different genes encode for NPC components, termed nucleoporins (Nups). Although specialized Nups have been identified in many species, extensive biochemical and structural studies in vitro led to the consensus that the core scaffold inventory is conserved. It consists of several Nup subcomplexes that come together in multiple copies to form an assembly of eight asymmetric units, called spokes, that are arranged in a rotationally symmetric fashion (1). The Y-complex (also called Nup107 complex) is the major component of the outer rings (the nuclear and cytoplasmic rings; NR and CR), which are placed distally into the nuclear and cytoplasmic compartments. The inner ring complex scaffolds the inner ring (IR; also called spoke ring) that resides at the fusion plane of the nuclear membranes. The Nup159 complex (also called Pcomplex) asymmetrically associates with the Y-complex of the cytoplasmic ring and mediates mRNA export. Despite these common features of quaternary structure, in situ structural biology studies have revealed that the higher order assembly is variable across the eukaryotic kingdom (2).

In addition to compositional variability across different species, NPC architecture is conformationally highly dynamic and variations in NPC diameter have been observed in various species and using different methods (3-7). It has been shown that dilation is part of the NPC assembly process $(8,9)$. However, if NPC dilation and constriction may play a role during active nuclear transport (10), or are required to open up peripheral channels for the import of inner nuclear membrane proteins (11-13), remains controversial. It is difficult to conceive that such large-scale conformational changes can occur on similar time scales as individual transport events $(14,15)$, which would be the essence of a physical gate. Nevertheless, several cues that potentially could affect NPC diameter have been suggested, such as exposure to mechanical NE stress, mutated forms of Importin $\beta$, varying $\mathrm{Ca}^{2+}$ concentrations or hexanediol $(7,16-21)$. However, these previous studies did neither explore NPC diameter and its functional consequences within intact cellular environments nor did they structurally analyze the conformational changes of nuclear pores in molecular detail. Thus, physiological cause and consequence along with the molecular mechanisms of NPC dilation and constriction remain enigmatic. 
bioRxiv preprint doi: https://doi org/101101/2020 07.30.228585; this version posted July 31 , 2020. The copyright holder for this preprint (which was not certified by peer review) is the author/funder, who has granted bioRxiv a license to display the preprint in perpetuity. It is made available under aCC-BY-NC-ND 4.0 International license.

Zimmerli, Allegretti et al

Active nuclear transport of cargo relies on energy supply. Importin or exportin-mediated transport requires the small GTPase RAN that binds either GTP in the nucleus or GDP in the cytoplasm to ensure directionality of transport (22), while mRNA export is directly ATP dependent (23). Cells of various organisms including Schizosaccharomyces pombe show a rapid shut down of active nuclear transport and mRNA export when depleted of ATP (24-26).

This points to a well conserved mechanism, likely dependent on a concomitantly reduced availability of free GTP (27). Moreover, energy depletion (ED) leads to a general reorganization of the cytoplasm including solidification of the periplasm, general water loss and reduction of the nuclear and cellular volume, which allows cells to endure under unfavorable conditions (28-31). If the shutdown of active nuclear transport coincides with the alteration in passive diffusion and potentially a conformational adaption of NPC architecture remains unknown.

Here we demonstrate that in S. pombe NPCs (SpNPCs) constrict under conditions of ED, which is concomitant with a reduction of both, free diffusion and active nuclear transport across the nuclear envelope. Using in cellulo cryo-electron microscopy (cryo-EM) and integrative structural modeling, we captured a molecular movie of NPC constriction. Our dynamic structural model suggests large scale conformational changes that occur by movements of the spokes with respect to each other but largely preserve the arrangement of individual subcomplexes. Previous structural models obtained from isolated nuclear envelopes (32-37) thereby represent the most constricted NPC state.

\section{In cellulo cryo-EM map of the S. pombe NPC}

To study NPC architecture and function in cellulo at the best possible resolution and structural preservation, we explored various genetically tractable model organisms for their compatibility with cryo-focused ion beam (FIB) specimen thinning, cryo-electron tomography and subtomogram averaging (STA). Saccharomyces cerevisiae cells were compatible with high throughput generation of cryo-lamellae and acquisition of tomograms. STA of their NPCS resulted in moderately resolved structures (4). In contrast, a larger set of cryo-tomograms 
bioRxiv preprint doi: https://doi org/10.1101/2020.07.30.228585. this version posted July 31, 2020. The copyright holder for this preprint (which was not certified by peer review) is the author/funder, who has granted bioRxiv a license to display the preprint in perpetuity. It is made available under aCC-BY-NC-ND 4.0 International license.

Zimmerli, Allegretti et al

106

107

108

109

110

111

112

113

114

115

116

117

118

119

120

121

122

123

124

125

126

127

128

129

130

131

132

133

134

135

136

137

with S. pombe cells that are small enough for thorough vitrification, offer a superior geometry for FIB-milling compared to $C$. thermophilum with the advantage of covering multiple cells and, compared to S. cerevisiae, higher number of NEs and NPCs per individual cryo-lamellae and tomogram, leading to high data throughput (Fig. S1).

To obtain a high quality cryo-EM map of S. pombe NPCs, we prepared cryo-FIB milled lamellae of exponentially growing S. pombe cells and acquired 178 tomograms from which we extracted 726 NPCs. Subsequent STA resulted in an in cellulo NPC average of very high quality in terms of both visible features (Fig. 1A, B and Fig. S2A) and resolution (Fig. S2B). Systematic fitting of the S. pombe IR asymmetric unit model (see Materials and Methods), resulted in a highly significant fit (Fig S3A). The subsequent refinement with integrative modeling led to a structural model that explains the vast majority of the observed electron optical density in the IR (Fig. 1B, Fig. S4, and Video S1). The IR architecture appears reminiscent to NPC structures of other eukaryotes (Fig. S5) further corroborating its evolutionary conservation (1).

Although the outer rings are known to be more variable, the intra-subcomplex interaction network of the Y-complex (Nup120, Nup85, Nup145C, Sec13, Nup84 and Nup133) has been comprehensively characterized by many studies and considered to be conserved (1) (see Table S1 for nomenclature of Nups across different species). Systematic fitting revealed that the NR of the SpNPC is composed of two concentric Y-complex rings (Fig. 1A, Fig. S3B and Video S1) as in vertebrates and algae but as opposed to the single Y-complex ring observed in S. cerevisiae (Fig. S2A) $(4,35,38)$. Integrative modeling of the entire Y-complex ensemble of the NR revealed a rather classical Y-complex architecture with the typical head-to-tail oligomerization (Fig. 2A and Fig. S4). This analysis emphasizes that S. pombe Y-complex Nups do localize to the NR, contrasting previous proposals (39). The homology models of SpNup131 and SpNup132 fit to the Y-complex tail region equally well, rendering these two proteins indistinguishable by our approach.

Closer inspection of the cytoplasmic side of cryo-EM map revealed a surprising and unprecedented architectural outline, since it did not form a ring. Instead, eight spatially separated entities were observed (Fig. 1A) suggesting that the integrity of the cylindrical 
bioRxiv preprint doi: https://doi.org/10.1101/2020.07.30.228585; this version posted July 31 , 2020. The copyright holder for this preprint (which was not certified by peer review) is the author/funder, who has granted bioRxiv a license to display the preprint in perpetuity. It is made available under aCC-BY-NC-ND 4.0 International license.

Zimmerli, Allegretti et al

outline is rather provided by the IR and NR while the cytoplasmic protein entities serve as a mere anchor point for the mRNA export platform, the Nup159 complex (Fig. 2B). Although the dynein-arm that is characteristic for the S. cerevisiae NPC (40) is lacking, the Nup159 complex resembles its S. cerevisiae counterpart in shape (Fig. S6A). Systematic fitting and subsequent refinement with integrative modeling revealed that the $Y$-complex vertex fits into the density observed at the cytoplasmic side (Fig. 2B, Fig. S3C, Fig. S4 and Video S1). The density potentially accounting for Nup107 and SpNup131/SpNup132 was missing (Fig. S3D) and could not be recovered by local refinement (Fig. S6B). Instead, the observed density sharply declined at the edge of SpNup189C consistent with previous work suggesting a split of the SpNup189C-Nup107 interface (Fig. S6C) $(39,41)$. To independently confirm the identity

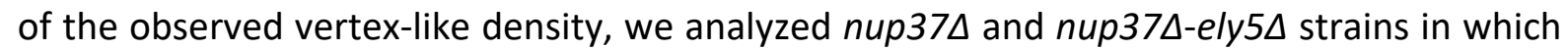
non-essential, peripheral Y-complex Nups were deleted. The binding of both, Nup37 and Ely5 to Nup120 has been previously shown in vitro $(42,43)$, and as expected, density was missing in the respective positions of all Y-complexes (Fig. 2C-D and Fig. S7A-B). Unexpectedly, a density that could accommodate Ely5 homology model was missing also in the cytoplasmic $\mathrm{Y}$ complex, suggesting that Ely5 is present in S. pombe at both, the nuclear and the cytoplasmic side of the NPC (Fig 2D and Video S1) unlike in higher metazoans where its homolog ELYS is known to exclusively bind to the NR $(35,44)$. Otherwise, the NPC architecture remained mostly unchanged, despite some increased flexibility in the Nup120 arm of the outer nuclear Y-complex (Fig. S7A-B). These results unambiguously identify the density observed at the cytoplasmic side as bona fide Y-complex vertex.

\section{Energy depletion leads to constriction of NPC scaffold and central channel}

Previous cryo-EM structures of NPCs obtained from isolated nuclear envelopes (32-37) or by detergent extraction (45) had a smaller diameter as compared to those obtained from intact cells $(3,4,38,46)$. We therefore hypothesized that NPC diameter may depend on the biochemical energy level that is depleted during preparations of isolated nuclear envelopes or NPCs but may also be reduced within intact cells e.g. during stress conditions. We set out to systematically analyze the NPC architecture under conditions of energy depletion as compared to exponentially growing cells. We structurally analyzed 292 NPCs subsequent to 1 hour of ED using non-hydrolysable 2-deoxy-glucose in combination with the respiratory chain inhibitor antimycin A (see Materials and Methods). We measured the diameter based 
bioRxiv preprint doi: https://doi.org/10.1101/2020.07.30.228585; this version posted July 31 , 2020. The copyright holder for this preprint (which was not certified by peer review) is the author/funder, who has granted bioRxiv a license to display the preprint in perpetuity. It is made available under aCC-BY-NC-ND 4.0 International license.

Zimmerli, Allegretti et al

170

171

172

173

174

175

176

177

178

179

180

181

182

183

184

185

186

187

188

189

190

191

192

193

194

195

196

197

198

199

200

201

on centroids of the spokes as obtained by STA (see Materials and Methods) and found a significant constriction of the mean central channel diameter during ED from $\sim 70 \mathrm{~nm}$ to $\sim 55$ $\mathrm{nm}$ (Fig. 3A). The variation of diameters was larger within the population of NPCs exposed to ED as compared to the actively transporting conditions, which likely blurred structural features during STA. To generate a conformationally more homogenous ensemble, we split the particles form the ED data set into two classes with central channel diameters of $<50 \mathrm{~nm}$ and $>50 \mathrm{~nm}$ (533 and 1012 subunits respectively) (Fig. 3B) and refined them separately to $<28$ Å resolution (Fig. 3C-D and Fig. S8A-B). Both conformations of the ED state showed a smaller NPC diameter compared to the control. The intermediate conformation was $\sim 65 \mathrm{~nm}$ wide at the IR while the most constricted conformation showed a diameter of $\sim 49 \mathrm{~nm}$ (Fig. 3D) and is thus comparable to the diameter observed in isolated NEs (32-37). We further calculated the diameters at the level of the cytoplasmic side and NR and found that all three rings constrict significantly during ED. While the diameter of the IR and cytoplasmic side changed their conformation most dramatically, the NR was less affected (Fig. 3E, Videos S4-S6). The estimated volume of the central channel in the most dilated state was almost twice as large $\left(\sim 152^{\prime} 000 \mathrm{~nm}^{3}\right)$ as compared to the most constricted state $\left(\sim 86^{\prime} 000 \mathrm{~nm}^{3}\right)$ (Fig. S8C), which likely translates to $\sim 2$-fold change in concentration of the FG-repeats contained therein.

To better understand how NPCs accommodate such massive conformational changes on the molecular level, we systematically fitted individual subcomplexes (Fig. S9) and built structural models of the three different diameter states based on the cryo-EM maps (Fig. 3C-D) using a multi-state integrative modeling procedure (Fig S4). In the cytoplasmic side and the NR, conformational changes were limited to the curvature of the Y-complexes and inwardbending of the mRNA export platform towards the center of the pore (Videos S4-6). In contrast, the central channel constriction of the IR is more elaborate and mediated by a lateral displacement of the 8 spokes that move as independent entities to constrict or dilate the IR (Fig. 3D and Videos S4-S6). In the dilated state, around 3-4 $\mathrm{nm}$ wide gaps are formed inbetween the neighboring spokes, while in the constricted state the spokes form extensive contacts (Fig. S10A-B), equivalent to those in the previously published structures of the human NPC in isolated nuclear envelopes (36). Notably, the spokes do not move entirely as rigid bodies, but some conformational changes occur within the Nup155 and Nsp1 complex regions (Video S7 and S8). Those are however distinct from the previously proposed 
bioRxiv preprint doi: https://doi org/10.1101/2020.07.30.228585; this version posted July 31 , 2020. The copyright holder for this preprint (which was not certified by peer review) is the author/funder, who has granted bioRxiv a license to display the preprint in perpetuity. It is made available under aCC-BY-NC-ND 4.0 International license.

Zimmerli, Allegretti et al

202

203

204

205

206

207

208

209

210

211

212

213

214

215

216

217

218

219

220

221

222

223

224

225

226

227

228

229

230

231

232

233

conformational sliding (10) and rather consistent with an overall preserved intra-subcomplex arrangement $(15,47)$.

Interestingly, under conditions of ED additional density is arching out into the lumen of the NE (Fig S10A and C), contrasting control conditions under which they are less clearly discernible from the membrane. It has been previously proposed that such luminal structures are formed by Pom152 (ScPom152 or HsGP210) $(48,49)$. In terms of their shape, the observed arches are reminiscent to those observed in isolated Xenopus laevis (34). Our data imply that the luminal ring conformation becomes more prominent upon constriction. If this has any mechanical benefits to keep NPCs separated (34), or might rather limit the maximal dilation, remains to be further investigated.

\section{NPC constriction is concomitant with reduced diffusion and active nuclear transport}

We wondered about the transport competence of NPCs in conditions under which they are constricted in comparison to actively transporting, dilated NPCs. To address this, we employed live cell imaging of $S$. pombe cells expressing a GFP variant tagged with a nuclear localization signal (NLS) on its N- and C-terminus (NLS-GFP) that shows a nuclear localization under control conditions (Fig. 4A). Already after 30 min of ED most of the NLS-GFP localized into the cytoplasm (Fig. 4 B), confirming that active nuclear import is suspended (26). To assess passive diffusion across the nuclear envelope, we performed fluorescence recovery after photobleaching (FRAP) experiments of nuclei in cells expressing freely diffusing GFP at different time points after ED as compared to control conditions (Fig. 4C and Fig. S11A-B) (see Materials and Methods). GFP diffusion rates into the nucleus were significantly decreased upon energy depletion (Fig. 4C), contrasting a minor, negligible effect observed within the cytoplasm (Fig. S11C). Passive diffusion was the slowest after about 1 hour of ED, the time at which we structurally analyzed NPC architecture and is thus concomitant with NPC constriction (Fig. 4C).

ED was shown to generally reduce cellular and nuclear volumes $S$. pombe cells $(28,29,31)$. We therefore hypothesized that changes of diameter of the NPC could be a result of a reduced nuclear size that may reduce mechanical strain imposed onto the NPC scaffold by the nuclear membranes. As a proxy for nuclear size we quantified the median nuclear projection surface 
bioRxiv preprint doi: https://doi.org/10.1101/2020.07.30.228585; this version posted July 31 , 2020. The copyright holder for this preprint (which was not certified by peer review) is the author/funder, who has granted bioRxiv a license to display the preprint in perpetuity. It is made available under aCC-BY-NC-ND 4.0 International license.

Zimmerli, Allegretti et al

234

235

236

237

238

239

240

241

242

243

244

245

246

247

248

249

250

251

252

253

254

255

256

257

258

259

260

261

262

263

264

and indeed found a highly significant reduction from $71 \mu \mathrm{m}^{2}$ to $<60 \mu \mathrm{m}^{2}$ under conditions of ED (Fig. 4D), while NE staining based on Nup60-mCherry fluorescence indicated NE wrinkling (Fig. 4A). This data therefore points to a general shrinkage of nuclei during ED. For a spherical nucleus, the observed changes in nuclear projection area correspond to a reduction of $\sim 15 \%$ in nuclear surface area and $\sim 25 \%$ in nuclear volume, which would be sufficient to cause a loss of NE tension (50) and may relax NPC scaffold into the constricted conformation (Fig S12).

\section{Discussion and Conclusion}

Here we have investigated the compositional and conformational plasticity of NPC architecture in intact cells. We demonstrate that SpNPC scaffold exhibits an unexpected subcomplex arrangement that is breaking the long-standing dogma of a three ringed architecture. Similar to vertebrates and green algae, two concentric $Y$-complex rings form the NR. On the cytoplasmic side, eight individual cytoplasmic Y-complex vertices that do not exhibit any head-to-tail connection and thus do not form a ring. Although we cannot entirely exclude that the $\mathrm{Y}$-complex tail is flexible at the cytoplasmic side and was thus not resolved during averaging, several lines of evidence argue against this. Previous biochemical analysis was suggestive of less tightly associated tail and vertex portions of the Y-complex in S. pombe (41). Another investigation suggested a non-isostoichiometric assembly of Y-complex members in vivo (39) and structural analysis of the Y-complex from yet another fungus, namely Myceliophthora thermophila, had demonstrated in vitro that Nup145C forms a stable fold and associates with the vertex in absence of Nup107 (51). Although the Y-complex does contain hinges $(32,51-54)$ that are likely important to facilitate large scale conformational changes, the Nup189C-Nup107 interface is not known to be flexible. Taken together with the fact that the observed electron optical density sharply declines at the respective site, it is very likely that the interface between SpNup189C (HsNup96) and SpNup107, which was thought to be conserved, is not formed in the cytoplasm but only in the nucleoplasm. A recent study forced SpNup107 to the cytoplasmic side by expression of a SpNup189C-SpNup107 fusion protein which led to re-localization of SpNup131 to the cytoplasmic side (39), and thus further supports the here observed absence of the cytoplasmic Y-complex tail. How precisely $S$. pombe cells spatially segregate the two different types of $\mathrm{Y}$-complexes remains uncertain. Our survey of public databases for splice variants, post-translational modifications and 
bioRxiv preprint doi: https://doi.org/10.1101/2020.07.30.228585; this version posted July 31 , 2020. The copyright holder for this preprint (which was not certified by peer review) is the author/funder, who has granted bioRxiv a license to display the preprint in perpetuity. It is made available under aCC-BY-NC-ND 4.0 International license.

Zimmerli, Allegretti et al

265

266

267

268

269

270

271

272

273

274

275

276

277

278

279

280

281

282

283

284

285

286

287

288

289

290

291

292

293

294

295

homologous structures did not yield significant clues. In contrast to vertebrates $(35,44), S$. pombe Ely5 is a member of both the nuclear and the cytoplasmic Y-complex vertex. It appears plausible that ELYS acquired additional functional domains during evolution of open mitosis in metazoans such as the $\mathrm{C}$-terminal disordered region and AT-hook to tether $\mathrm{Y}$-complexes to NPC seeding sites on chromatin and consequently to the nuclear side of the NE.

We further show how conformational changes in NPC architecture mediate its constriction and dilation within intact cells in response to a defined physiological cue, namely the energy status of the cell. ED leads to a massive constriction of the central channel that results in a $\sim 2$-fold loss in volume and is concomitant with a reduction of passive diffusion across the NE, while active nuclear transport is completely shut down. If the observed reductions of molecular exchange are directly or indirectly related to the NPC constriction remains challenging to address, given the manifold processes occurring in cells entering quiescence in response to $\operatorname{ED}(28-30,55,56)$. It however appears plausible that a reduction of the nuclear pore central channel volume limits the diffusion rate. In fact it has been suggested that NPCS reduce the diffusion rate of passively translocating molecules in response to their molecular size, rather than showing a strict size exclusion threshold (57). It has been further shown that active nuclear transport does not enhance passive diffusion $(58,59)$ and several studies have shown that cytoplasmic diffusion of small proteins, such as soluble mCherry, is not significantly affected during ED (28). Finally, a recent study showed that the uptake and partitioning of both passively diffusing and nuclear transport factor (NTF)-like molecules by FG-domain in vitro is directly dependent on the their concentration (60). All of which agrees well with our findings. It therefore is plausible that a constricted central channel volume leads to an increased local FG-domain concentration which in turn limits the passive diffusion of molecules of a constant size, similar to the diffusion limitation observed in response to increasing molecular size under control conditions.

Peripheral channels are thought to be important for the nuclear import of inner nuclear membrane proteins (11-13). Here we observed around 3-4 $\mathrm{nm}$ wide lateral gaps between the individual spokes of actively transporting NPCs. Notably, our data processing workflow yields an average of conformation under the respective conditions and individual spokes are even 
bioRxiv preprint doi: https://doi.org/10.1101/2020 07 30.228585. this version posted July 31 2020. The copyright holder for this preprint (which was not certified by peer review) is the author/funder, who has granted bioRxiv a license to display the preprint in perpetuity. It is made available under aCC-BY-NC-ND 4.0 International license.

Zimmerli, Allegretti et al

296

more dynamic ((6) and this study). Therefore, it is plausible that the opening and closing of

peripheral channels may regulate the translocation of inner nuclear membrane proteins.

Based on crystal structures of fragments of the Nsp1 (HsNup62) complex, it had been previously suggested that NPCs undergo dilation cycles that involve refolding and alternative configurations of the coiled-coil domains of the complex (61). The conformational changes observed in this study are very different. They do not necessitate a rearrangement of subcomplex folds but are rather based on large scale movements (Videos S4-S7). Such movements may also be relevant during NPC assembly or turnover, where significant smaller diameters have been observed $(4,8,9)$.

How ED mechanically leads to NPC constriction remains to be further addressed in the future. It appears likely that a reduced nuclear volume relieves NE tension and in turn allows NPCs to constrict (50). At this point, we cannot exclude additional factors such as the previously reported cellular $\mathrm{pH}$-change during $\operatorname{ED}(28,29)$ or the shut-down of active nuclear transport itself to have an effect on NTF occupancy and NPC conformation. However, mechanical tension on the NE and active nuclear transport are certainly diminished during NE or NPC isolation. Therefore, previous structural analysis of such preparations has yielded structures

314 that correspond to the most constricted conformation at the very end of the scale.

316 In conclusion we show that NPCs within livings cells populate a much larger conformational

317 space and thereby confirm their importance as regulators of nucleocytoplasmic transport in 318 response to environmental cues in living organisms on a cellular level. Hence our study 319 highlights the power and importance of in cellulo structural analyzes to study such crucial physiological processes at the macromolecular level within the relevant cellular environment. 
bioRxiv preprint doi: https://doi.org/10.1101/2020 07.30.228585; this version posted July 31, 2020. The copyright holder for this preprin (which was not certified by peer review) is the author/funder, who has granted bioRxiv a license to display the preprint in perpetuity. It is made available under aCC-BY-NC-ND 4.0 International license.

Zimmerli, Allegretti et al

321

A
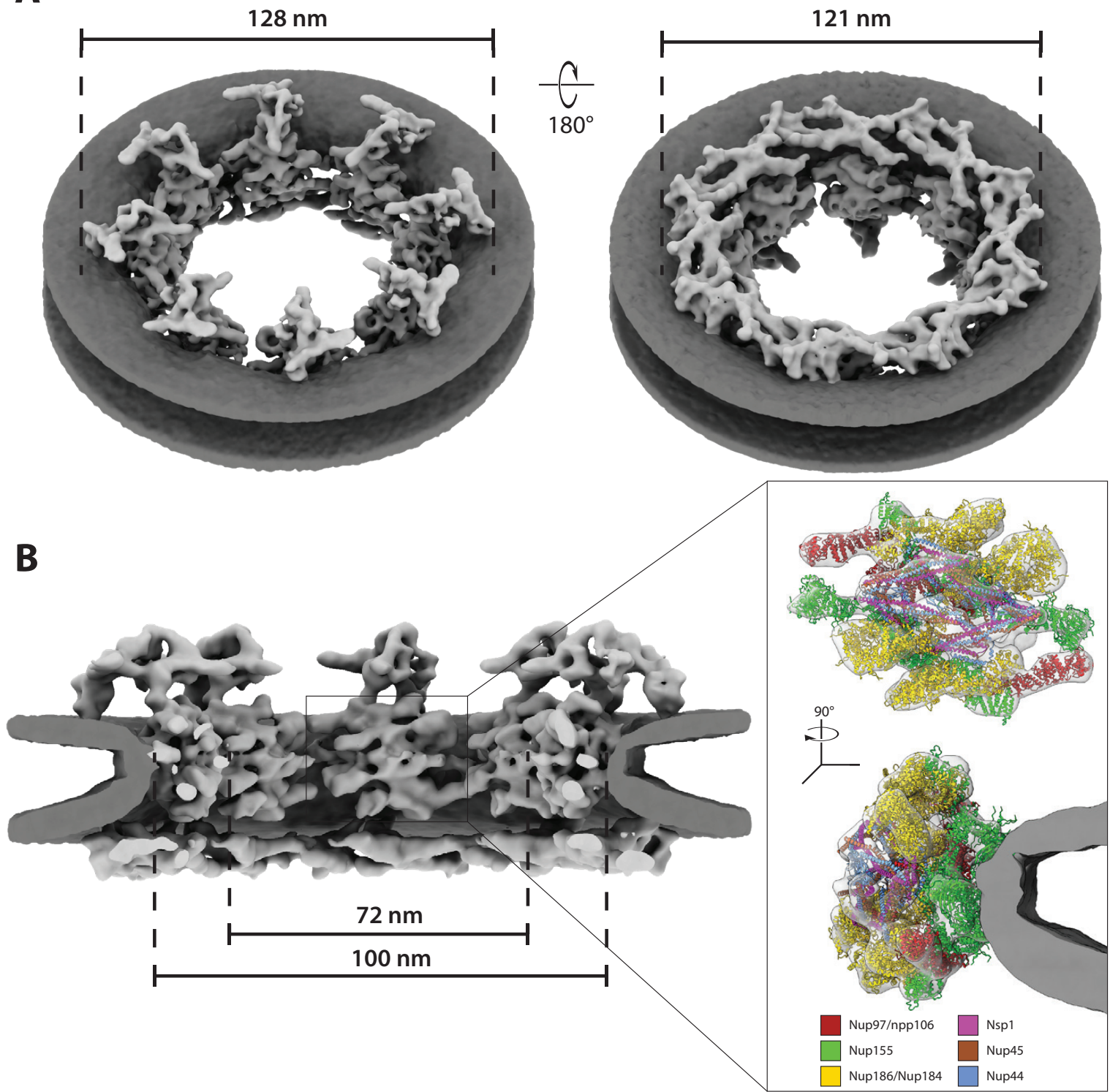

Figure 1. In cellulo cryo-EM map of the S. pombe NPC. A) Isosurface rendered views of the $S$. pombe NPC as seen from the cytoplasm (left) and the nucleoplasm (right; with membranes in dark and protein in light grey). While the cytoplasmic view (left) reveals eight disconnected protein entities instead of a cytoplasmic ring, the nuclear view (right) shows two concentric nuclear Y-complex rings. B) Same as (A) but shown as cutaway view. While the asymmetric curvature of the nuclear membranes and the arrangement of the cytoplasmic side is unprecedented in other species, the inner ring architecture is highly conserved as highlighted in the inset (see also Fig. S5). Fitting of inner ring nucleoporin homology models explains the vast majority of the observed electron optical density. 
Zimmerli, Allegretti et al

A

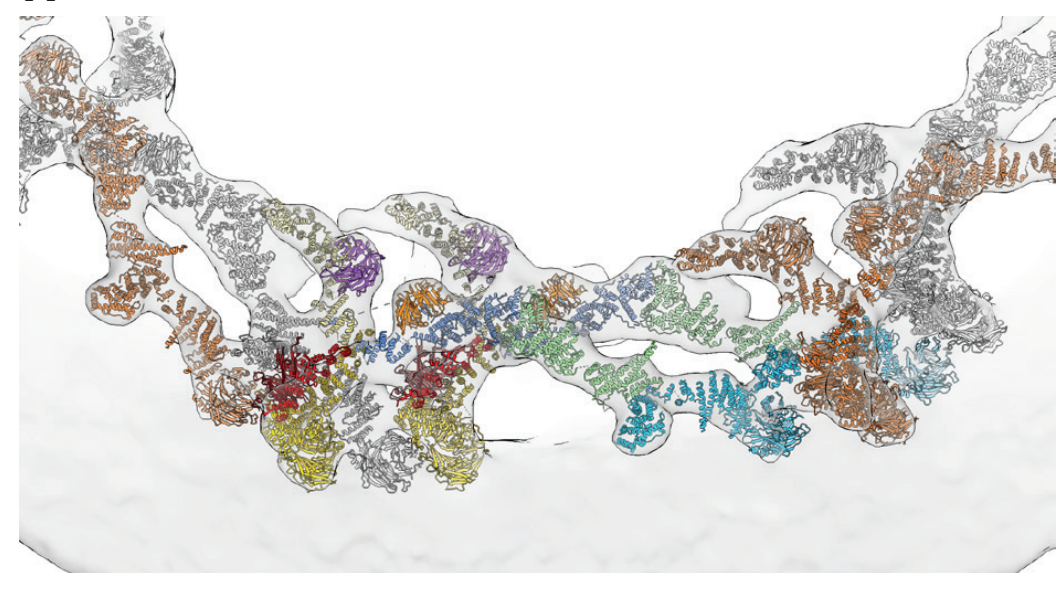

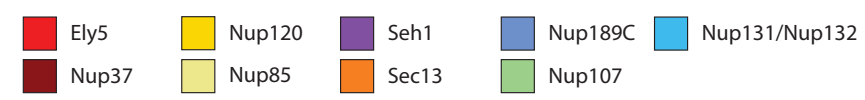

C

333

334

335

336

337

338

339

340

341

342

343

344

345

346

347 Ely5 (light red) with respect to the fitted Y-complex model (dark grey).
D

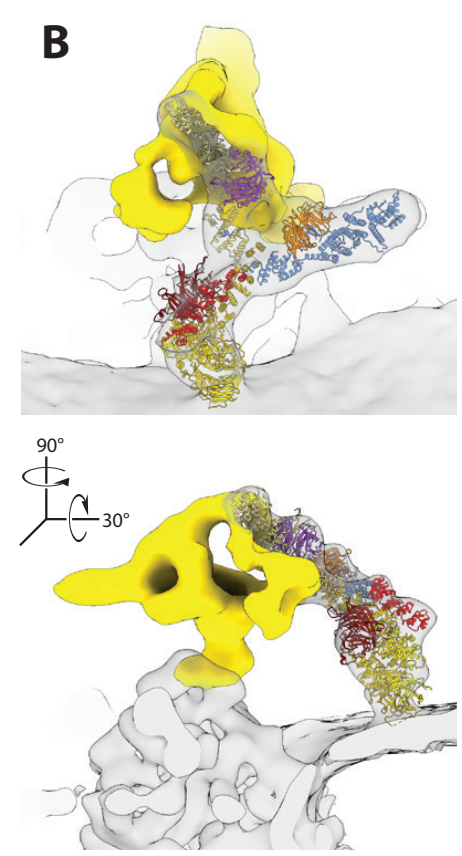

$\stackrel{90^{\circ}}{+} \mathrm{L}_{30^{\circ}} \quad$ Nup37 Ely5

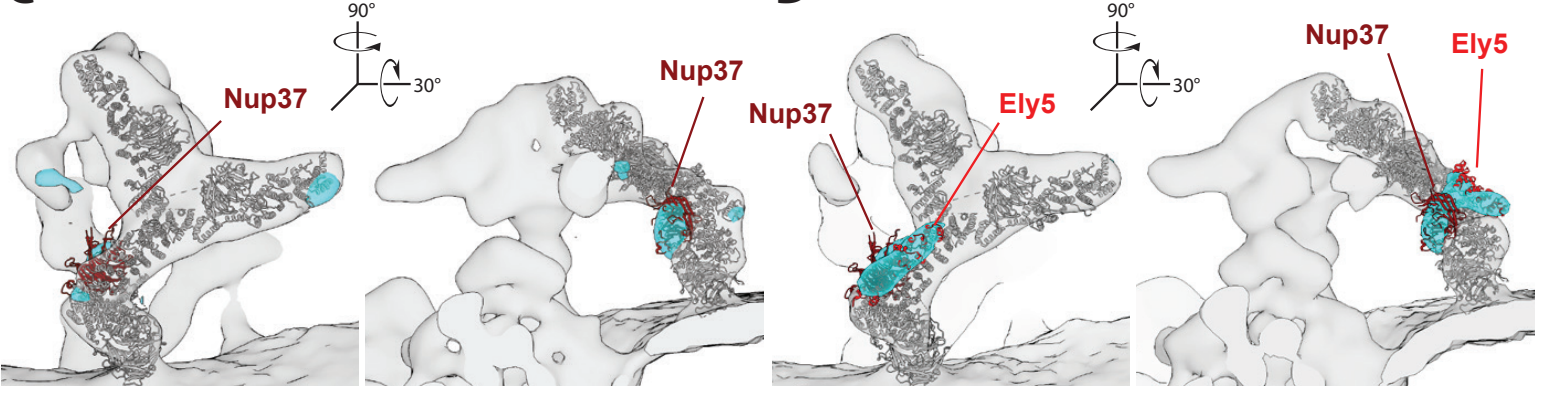

Figure 2. Architecture of spNPC outer rings. A) Systematic fitting and integrative modeling of

all S. pombe Y-complex nucleoporins reveals a head-to-tail arrangement with two concentric Y-complex rings on the nuclear side of the SpNPC similar to humans. A segment of the NR of the cryo-EM map is shown isosurface rendered in transparent light grey. The adjacent inner Y-complexes are shown in grey and outer Y-complexes are shown in orange. B) Integrative model of the cytoplasmic protein entities. The fit of the Y-complex vertex explains most of the observed density. The mRNA export platform as identified in $(4,62)$ is segmented in yellow. C, D) Verification of the molecular identity of the observed structure. C) The nup37D cryo-EM map is shown in light grey and overlaid with the difference map (cyan) of the wild type and nup37 maps, both filtered to $27 \AA$. The missing density in the long arm of the Yvertex coincidences with the position of Nup37 (dark red) of the Y-complex vertex (dark grey, as in A). D) nup374-ely5 double knockout map (light grey) overlaid with the corresponding difference map (cyan). Differences are apparent at the location of both, Nup37 (dark red) and 
bioRxiv preprint doi: https://doi.org/10.1101/2020.07.30.228585; this version posted July 31, 2020. The copyright holder for this preprint (which was not certified by peer review) is the author/funder, who has granted bioRxiv a license to display the preprint in perpetuity. It is made available under aCC-BY-NC-ND 4.0 International license.

Zimmerli, Allegretti et al

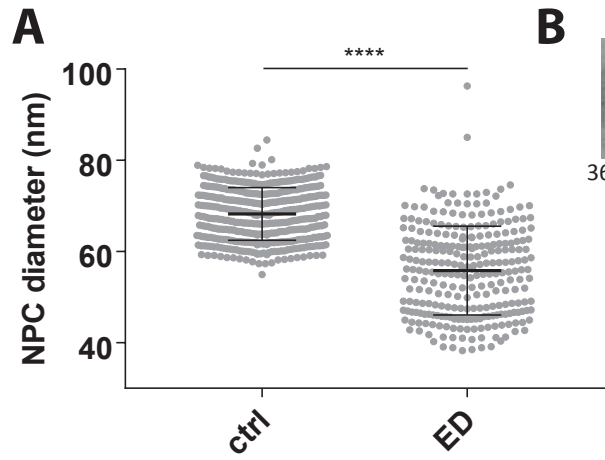

C
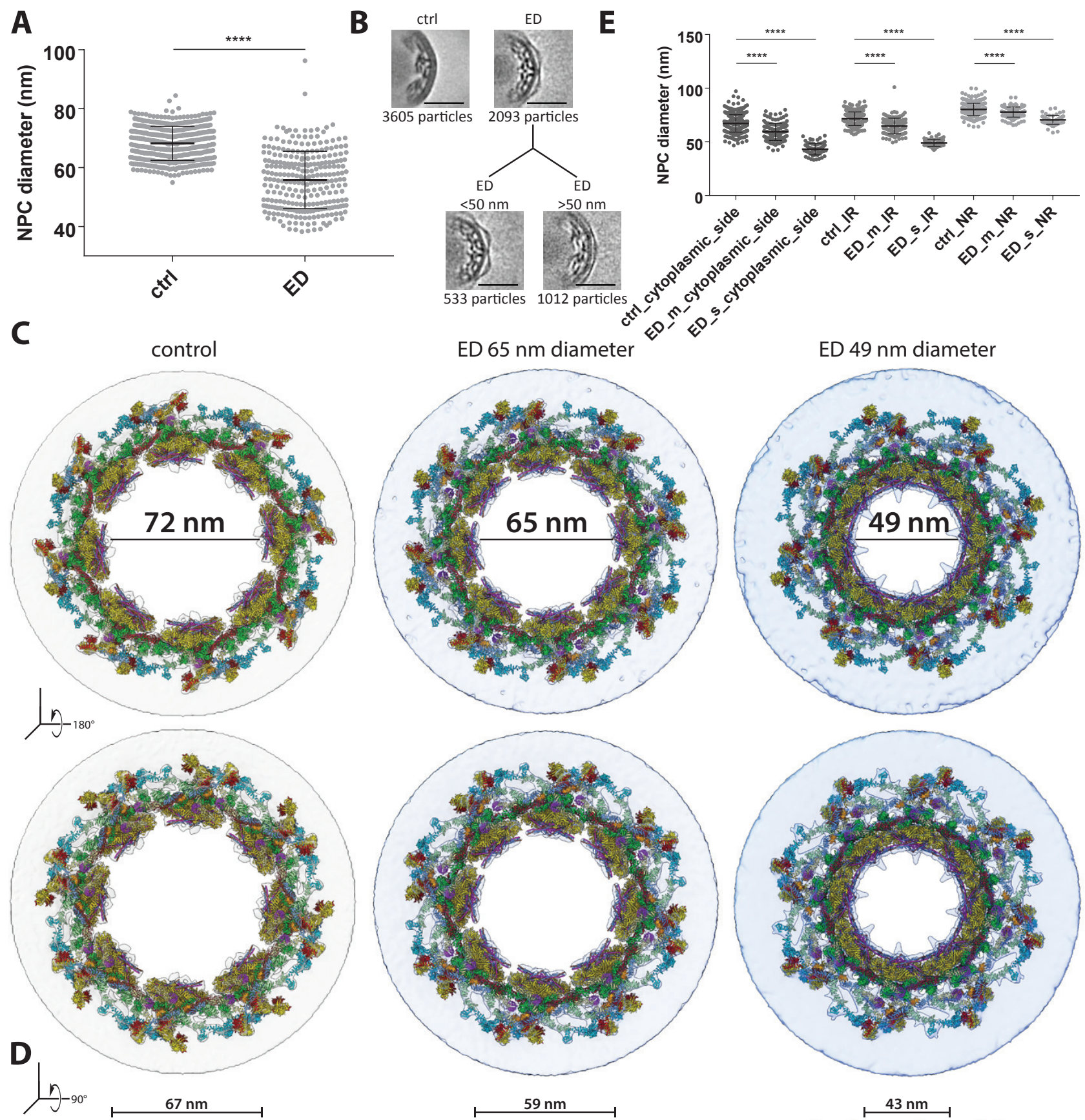

ED $65 \mathrm{~nm}$ diameter
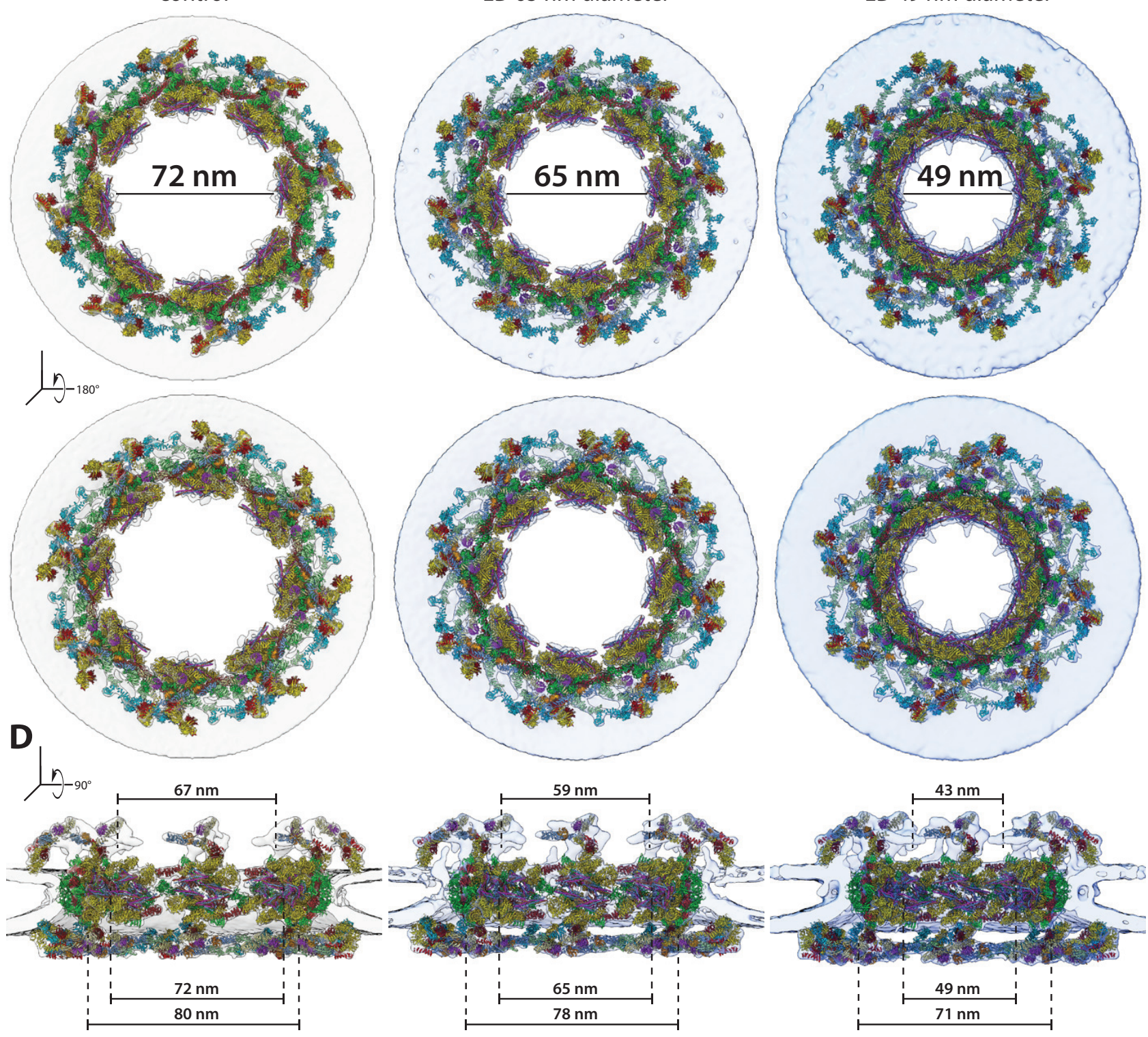

Nup97/npp106
$\square$ Nup155
$\square$ Nup186/Nup184

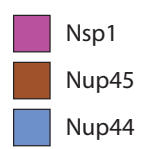

Nup37 $\square$ Nup85

Nup189C

Nup107

Nup131/Nup132 
Zimmerli, Allegretti et al

349

350

351

352

353

354

355

356

357

358

359

360

361

362

363

364

365

366

367

368

369

370

371

372

373

Figure 3. NPCs constrict upon energy depletion. A) Diameter measurement of control $(n=438)$ and energy depleted ( $n=271$ ) NPCs based on subunit positions obtained by STA (see Materials and methods) reveals a significant constriction of NPCs upon ED (mean \pm standard error of mean (SdEM) control: $68.2 \mathrm{~nm}$ and mean ED: $55.84 \mathrm{~nm}$, whiskers indicate standard deviation, $\mathrm{p}$-value $<0.0001$, two-sided t-test). B) Slices through subtomogram averages corresponding to $(A)$ show the different conformations at the level of the IR. NPCs were divided into two classes with diameters of $<50 \mathrm{~nm}$ (left) and $>50 \mathrm{~nm}$ (right; scale bar: 50 $\mathrm{nm}$ ). C) Measurements of individual NPC diameters at the CR, IR and NR in control conditions and during ED reveal significant diameter constriction of all three rings (all pvalues $<0.0001$; ctrl control; ED_m represents the class with diameter of $>50 \mathrm{~nm}$; ED_S represents the class with diameter of $<50 \mathrm{~nm}$. Diameters mean \pm SdEM measured are: 67.25 $\pm 0.44, \mathrm{n}=341$ (ctrl_cytoplasmic_side); $59.29 \pm 0.6817, \mathrm{n}=136$ (ED_m_cytoplasmic_side) and $43.15 \pm 0.6509, \mathrm{n}=68$ (ED_s_cytoplasmic_side); $71.59 \pm 0.3459, \mathrm{n}=341$ (ctrl_IR); $64.73 \pm$ $0.626, \mathrm{n}=136$ (ED_m_IR) and $49 \pm 0.3815, \mathrm{n}=68$ (ED_s_IR); $80.22 \pm 0.3106, \mathrm{n}=341$ (ctrl_NR); $77.71 \pm 0.4006, n=136$ (ED_m_NR) and $70.59 \pm 0.5001, n=68$, whiskers indicate standard deviation. D) Cytoplasmic view (top) and nuclear view (bottom) of cryo-EM maps superimposed with the respective integrative models from actively transporting, intermediate and fully constricted NPCs illustrating the overall conformational change leading to a central channel diameter constriction from $72 \mathrm{~nm}$ to $49 \mathrm{~nm}$. The cytoplasmic and IR spokes move as individual entities and contribute the most to the central channel diameter change, whereas the NR constricts to a lesser extent. E) Same as (D) but show as cutaway side view. Upon constriction, the mRNA export platform bends towards the center of the NPC. Conformational changes of the NR are less dramatic and include mostly changes in the curvature of the $\mathrm{Y}$ complexes (see also supplementary videos 4-8).

Page 15 of 65 
Zimmerli, Allegretti et al

A

A
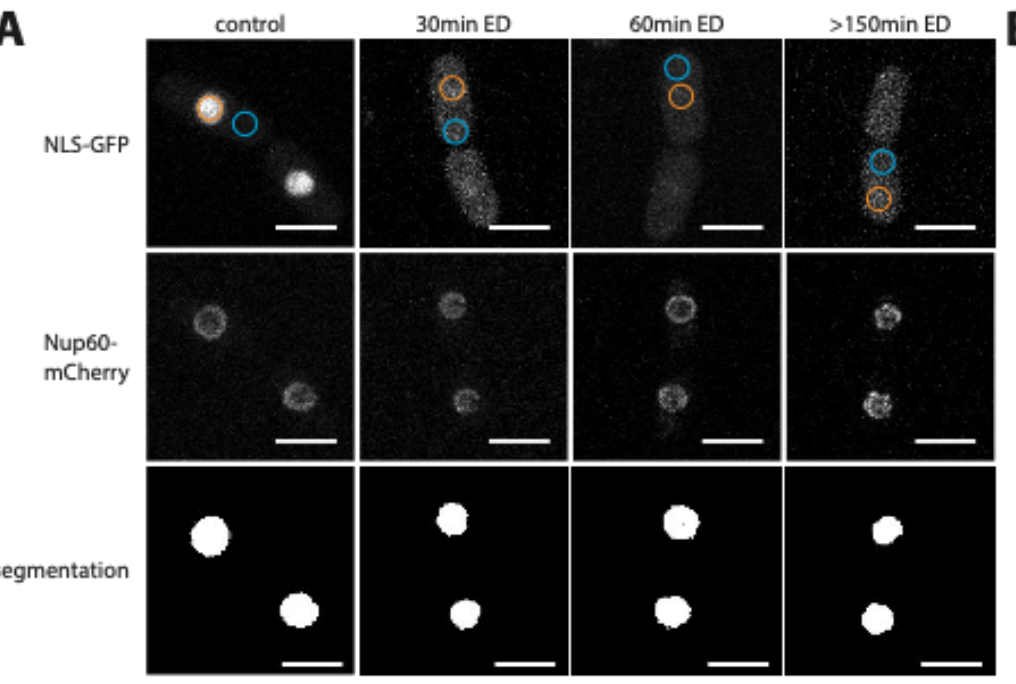

$60 \mathrm{~min} E D$ $>150 \mathrm{~min} E \mathrm{E}$

\section{B} Quantification of active nuclear import

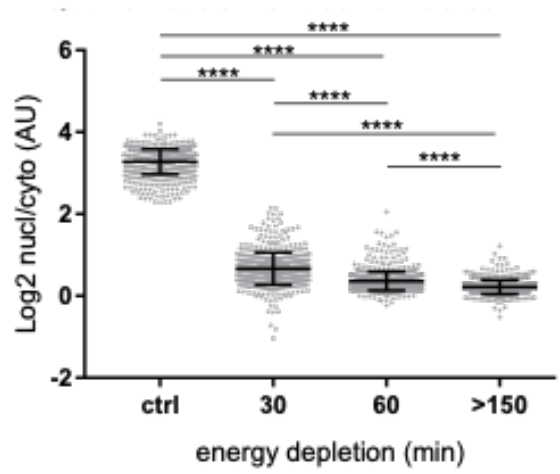

C

Passive nuclear cytoplasmic diffusion

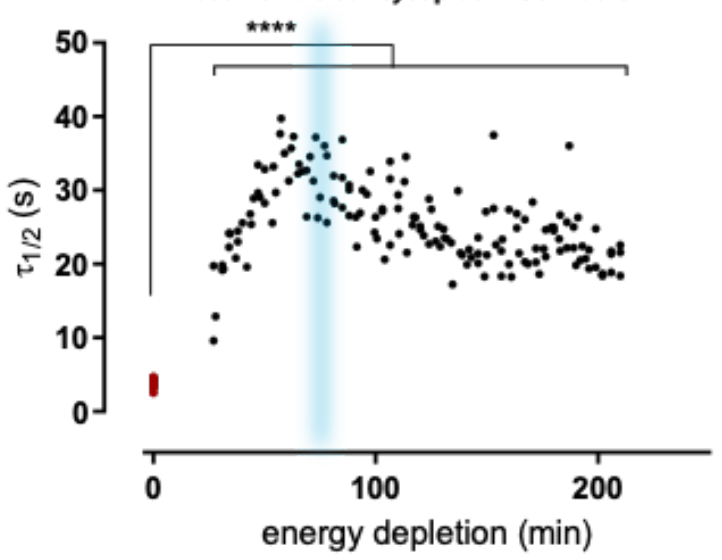

D

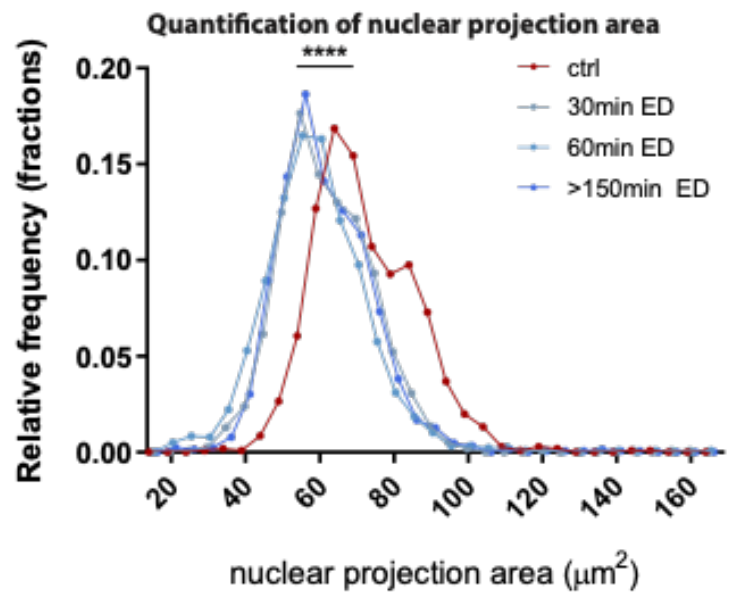

Figure 4 How energy depletion affects transport across the nuclear envelope and nuclear

size. A) Maximum projected confocal stack from life cell imaging of NLS-GFP and Nup60-

mCherry are used to measure active nuclear transport and nuclear size during energy depletion. Actively imported NLS-GFP loses its nuclear localization during ED indicating a shutdown of active nuclear transport during ED. The nuclear projection area is reduced during ED as determined by segmenting the Nup60-mCherry NE signal, indicating a reduced nuclear volume. Orange (nuclear) and blue (cytoplasmic) circles indicate areas used for quantification of the GFP signal. Nuclear projection areas were determined in the mCherry-channel using automated segmentation (see Materials and Methods) (scale bar: $5 \mu \mathrm{m}$ ). B) Quantification of nuclear/cytoplasmic signal shows a significant leakage of NLS-GFP into the cytoplasm and thus indicates a shutdown of active nuclear transport already after $30 \mathrm{~min}$ of ED. The observed mean log2 fold change were: $3.276(n=623)$ under control conditions; $0.662(n=584)$ after 30 min; $0.3654(n=722) 60 \mathrm{~min}$ and $0.2144(n=604)>150 \mathrm{~min}$ after ED (all adjusted $p$-values 
Zimmerli, Allegretti et al

402

403

404

405

406

407

408

409

410

411

412

half-life times of nuclear signal from freely diffusing GFP at various time points after ED are significantly longer during ED as compared to control conditions (red dots) ( $p$-value $<0.0001$, two-sided unpaired t-test) indicating a general down regulation of passive diffusion under these conditions. Passive nuclear diffusion of free GFP reaches a minimum after $\sim 1$ hour of ED and subsequently recovers slightly, pointing to cellular adaptation. The blue area shows the timepoint at which cryo-EM grids were prepared for structural analysis of ED NPCs. D) Histogram of quantified nuclear projection areas measured in segmented mCherry-channel of life-cell imaging as shown in $(A)$ reveal a significant shift towards smaller values during ED (blue curves) as compared to control conditions (red curve) indicating a general loss of nuclear volume during ED that also manifest in NE wrinkling as seen in (A) (all adjusted p-values are $<0.0001$, one-way ordinary ANOVA and Holm-Sidak's multiple comparison test with $n=1056$ control, $n=116830 \mathrm{~min}, \mathrm{n}=215360 \mathrm{~min}$ and $\mathrm{n}=1255>150 \mathrm{~min}$ after ED).

\section{Supplementary Material}

Materials and Methods

Supplementary figures 1-12

\section{Supplementary tables 1-3}

\section{Supplementary videos 1-7}

\section{Author contributions}

CEZ conceived the project, designed and performed experiments, acquired all types of data, designed and established data analysis procedures, analyzed all types of data, wrote the manuscript; MA conceived the project, designed and performed experiments, acquired data, analyzed data, wrote the manuscript; VR analyzed data, wrote the manuscript; SG designed and performed experiments, acquired data; AOK analyzed data; IZ designed and performed experiments; AH designed and performed experiments; JM designed experiments, supervised the project, JK conceived the project, designed and established data analysis procedures, 
Zimmerli, Allegretti et al

analyzed data, supervised the project, wrote the manuscript; MB conceived the project, designed experiments, supervised the project, wrote the manuscript.

\section{Competing interests}

423 Authors declare no competing interests.

\section{Data availability}

426 Associated with the manuscript are accession numbers EMD-11373, EMD-11374, EMD-

427 11375. Integrative models will be deposited into the PDBDEV upon publication. The code, 428 along the input files, for the modeling will be deposited in Zenodo upon publication.

\section{Acknowledgements}

We thank Beata Turoňová, Nikola Kellner, Wim Hagen, Felix Weiss, Christian Tischer, Janina Baumbach, Ed Hurt, Edward Lemke as well as all the members of the Mahamid, Kosinski and Beck laboratories for advice and support. We thank Ed Hurt, Buzz Baum, Thomas Schwartz and Christian Häring for providing yeast strains. We acknowledge support from the Electron Microscopy Core Facility, the Advanced Light Microscopy Facility and IT services of EMBL Heidelberg. MA was funded by an EMBO a long-term fellowship (ALTF-1389-2016); JM received funding from the European Research Council (ERC 3DCellPhase- 760067). MB acknowledges funding by EMBL, the Max Planck Society and the European Research Council (ComplexAssembly 724349).

\section{References}

443 1. D. H. Lin, A. Hoelz, The Structure of the Nuclear Pore Complex (An Update). Annu. 444 Rev. Biochem. 88, 725-783 (2019).

445 2. M. Beck, S. Mosalaganti, J. Kosinski, From the resolution revolution to evolution: structural insights into the evolutionary relationships between vesicle coats and the

448 3. J. Mahamid, S. Pfeffer, M. Schaffer, E. Villa, R. Danev, L. K. Cuellar, F. Förster, A. A. 
bioRxiv preprint doi: https://doi org/10.1101/2020 07 30.228585. this version posted July 31 2020. The copyright holder for this preprint (which was not certified by peer review) is the author/funder, who has granted bioRxiv a license to display the preprint in perpetuity. It is made available under aCC-BY-NC-ND 4.0 International license.

Zimmerli, Allegretti et al

449

450

451

452

453

454

455

456

457

458

459

460

461

462

463

464

465

466

467

468

469

470

471

472

473

474

475

476

477

478

479

480

Hyman, J. M. Plitzko, W. Baumeister, Visualizing the molecular sociology at the HeLa cell nuclear periphery. Science (80-. ). 351, 969-972 (2016).

4. M. Allegretti, C. E. Zimmerli, V. Rantos, F. Wilfling, P. Ronchi, H. K. H. Fung, C.-W. Lee, W. Hagen, B. Turonova, K. Karius, X. Zhang, C. Müller, Y. Schwab, J. Mahamid, B. Pfander, J. Kosinski, M. Beck, In cell architecture of the nuclear pore complex and snapshots of its turnover. in revison (2020).

5. G. J. Stanley, A. Fassati, B. W. Hoogenboom, Atomic force microscopy reveals structural variability amongst nuclear pore complexes. Life Sci. Alliance. 1 (2018), doi:10.26508/Isa.201800142.

6. M. Beck, V. Lǔí, F. Förster, W. Baumeister, O. Medalia, V. Lucić, F. Förster, W. Baumeister, O. Medalia, Snapshots of nuclear pore complexes in action captured by cryo-electron tomography. Nature. 449, 611-615 (2007).

7. J. Sellés, M. Penrad-Mobayed, C. Guillaume, A. Fuger, L. Auvray, O. Faklaris, F. Montel, Nuclear pore complex plasticity during developmental process as revealed by super-resolution microscopy. Sci. Rep. 7 (2017), doi:10.1038/s41598-017-15433-2.

8. S. Otsuka, A. M. Steyer, M. Schorb, J. K. Hériché, M. J. Hossain, S. Sethi, M. Kueblbeck, Y. Schwab, M. Beck, J. Ellenberg, Postmitotic nuclear pore assembly proceeds by radial dilation of small membrane openings. Nat. Struct. Mol. Biol. 25, 21-28 (2018).

9. S. Otsuka, K. H. Bui, M. Schorb, M. Julius Hossain, A. Z. Politi, B. Koch, M. Eltsov, M. Beck, J. Ellenberg, Nuclear pore assembly proceeds by an inside-out extrusion of the nuclear envelope. Elife. 5 (2016), doi:10.7554/eLife.19071.

10. J. Koh, G. Blobel, Allosteric regulation in gating the central channel of the nuclear pore complex. Cell. 161, 1361-1373 (2015).

11. A. C. Meinema, J. K. Laba, R. A. Hapsari, R. Otten, F. A. A. Mulder, A. Kralt, G. Van Den Bogaart, C. P. Lusk, B. Poolman, L. M. Veenhoff, Long unfolded linkers facilitate membrane protein import through the nuclear pore complex. Science (80-. ). 333, 9093 (2011).

12. R. Ungricht, M. Klann, P. Horvath, U. Kutay, Diffusion and retention are major determinants of protein targeting to the inner nuclear membrane. J. Cell Biol. 209, 687-704 (2015).

13. A. Boni, A. Z. Politi, P. Strnad, W. Xiang, M. J. Hossain, J. Ellenberg, Live imaging and modeling of inner nuclear membrane targeting reveals its molecular requirements in 
bioRxiv preprint doi: https://doi.org/10.1101/2020 07 30.228585. this version posted July 31 2020. The copyright holder for this preprint (which was not certified by peer review) is the author/funder, who has granted bioRxiv a license to display the preprint in perpetuity. It is made available under aCC-BY-NC-ND 4.0 International license.

Zimmerli, Allegretti et al

481

482

483

484

485

486

487

488

489

490

491

492

493

494

495

496

497

498

499

500

501

502

503

504

505

506

507

508

509

510

511

512

mammalian cells. J. Cell Biol. 209, 705-720 (2015).

14. H. Chug, S. Trakhanov, B. B. Hülsmann, T. Pleiner, D. Görlich, Crystal structure of the metazoan Nup62•Nup58•Nup54 nucleoporin complex. Science (80-. ). 350, 106-110 (2015).

15. T. Stuwe, C. J. Bley, K. Thierbach, S. Petrovic, S. Schilbach, D. J. Mayo, T. Perriches, E. J. Rundlet, Y. E. Jeon, L. N. Collins, F. M. Huber, D. H. Lin, M. Paduch, A. Koide, V. Lu, J. Fischer, E. Hurt, S. Koide, A. A. Kossiakoff, A. Hoelz, Architecture of the fungal nuclear pore inner ring complex. Science (80-. ). 350, 56-64 (2015).

16. V. Shahin, T. Danker, K. Enss, R. Ossig, H. Oberleithner, Evidence for Ca2+- and ATPsensitive peripheral channels in nuclear pore complexes. FASEB J. 15, 1895-1901 (2001).

17. D. Stoffler, K. N. Goldie, B. Feja, U. Aebi, Calcium-mediated structural changes of native nuclear pore complexes monitored by time-lapse atomic force microscopy. J. Mol. Biol. 287, 741-752 (1999).

18. A. Rakowska, T. Danker, S. W. Schneider, H. Oberleithner, ATP-induced shape change of nuclear pores visualized with the atomic force microscope. J. Membr. Biol. 163, 129-136 (1998).

19. L. Kastrup, H. Oberleithner, Y. Ludwig, C. Schafer, V. Shahin, Nuclear envelope barrier leak induced by dexamethasone. J. Cell. Physiol. 206, 428-434 (2006).

20. I. Liashkovich, A. Meyring, A. Kramer, V. Shahin, Exceptional structural and mechanical flexibility of the nuclear pore complex. J. Cell. Physiol. 226, 675-682 (2011).

21. R. D. Jäggi, A. Franco-Obregón, P. Mühlhäusser, F. Thomas, U. Kutay, K. Ensslin, Modulation of nuclear pore topology by transport modifiers. Biophys. J. 84, 665-670 (2003).

22. D. Görlich, N. Panté, U. Kutay, U. Aebi, F. R. Bischoff, Identification of different roles for RanGDP and RanGTP in nuclear protein import. EMBO J. 15, 5584-5594 (1996).

23. M. Stewart, Nuclear export of mRNA. Trends Biochem. Sci. 35 (2010), pp. 609-617.

24. W. D. Richardson, A. D. Mills, S. M. Dilworth, R. A. Laskey, C. Dingwall, Nuclear protein migration involves two steps: Rapid binding at the nuclear envelope followed by slower translocation through nuclear pores. Cell. 52, 655-664 (1988).

25. N. Shulga, P. Roberts, Z. Gu, L. Spitz, M. M. Tabb, M. Nomura, D. S. Goldfarb, "In vivo 
bioRxiv preprint doi: https://doi org/10.1101/2020 07 30.228585. this version posted July 31 2020. The copyright holder for this preprint (which was not certified by peer review) is the author/funder, who has granted bioRxiv a license to display the preprint in perpetuity. It is made available under aCC-BY-NC-ND 4.0 International license.

Zimmerli, Allegretti et al

513

514

515

516

517

518

519

520

521

522

523

524

525

526

527

528

529

530

531

532

533

534

535

536

537

538

539

540

541

542

543

544

nuclear transport kinetics in Saccharomyces cerevisiae: A role for heat shock protein 70 during targeting and translocation" (1996), , doi:10.1083/jcb.135.2.329.

26. W. A. Whalen, J. H. Yoon, R. Shen, R. Dhar, Regulation of mRNA export by nutritional status in fission yeast. Genetics. 152, 827-838 (1999).

27. E. D. Schwoebel, T. H. Ho, M. S. Moore, The mechanism of inhibition of Randependent nuclear transport by cellular ATP depletion. J. Cell Biol. 157, 963-974 (2002).

28. M. C. Munder, D. Midtvedt, T. Franzmann, E. Nüske, O. Otto, M. Herbig, E. Ulbricht, P. Müller, A. Taubenberger, S. Maharana, L. Malinovska, D. Richter, J. Guck, V. Zaburdaev, S. Alberti, A pH-driven transition of the cytoplasm from a fluid- to a solidlike state promotes entry into dormancy. Elife. 5 (2016), doi:10.7554/eLife.09347.

29. R. P. Joyner, J. H. Tang, J. Helenius, E. Dultz, C. Brune, L. J. Holt, S. Huet, D. J. Müller, K. Weis, A glucose-starvation response regulates the diffusion of macromolecules. Elife. 5 (2016), doi:10.7554/eLife.09376.

30. G. Marini, E. Nüske, W. Leng, S. Alberti, G. Pigino, Reorganization of budding yeast cytoplasm upon energy depletion. Mol. Biol. Cell. 31, 1232-1245 (2020).

31. M. B. Heimlicher, M. Bächler, M. Liu, C. Ibeneche-Nnewihe, E. L. Florin, A. Hoenger, D. Brunner, Reversible solidification of fission yeast cytoplasm after prolonged nutrient starvation. J. Cell Sci. 132 (2019), doi:10.1242/jcs.231688.

32. K. H. Bui, A. Von Appen, A. L. Diguilio, A. Ori, L. Sparks, M. T. Mackmull, T. Bock, W. Hagen, A. Andrés-Pons, J. S. Glavy, M. Beck, Integrated structural analysis of the human nuclear pore complex scaffold. Cell. 155, 1233-1243 (2013).

33. M. Eibauer, M. Pellanda, Y. Turgay, A. Dubrovsky, A. Wild, O. Medalia, Structure and gating of the nuclear pore complex. Nat. Commun. 6 (2015), doi:10.1038/ncomms8532.

34. Y. Zhang, S. Li, C. Zeng, G. Huang, X. Zhu, Q. Wang, K. Wang, Q. Zhou, C. Yan, W. Zhang, G. Yang, M. Liu, Q. Tao, J. Lei, Y. Shi, Molecular architecture of the luminal ring of the Xenopus laevis nuclear pore complex. Cell Res. 30, 532-540 (2020).

35. A. von Appen, J. Kosinski, L. Sparks, A. Ori, A. L. DiGuilio, B. Vollmer, M.-T. T. Mackmull, N. Banterle, L. Parca, P. Kastritis, K. Buczak, S. Mosalaganti, W. Hagen, A. Andres-Pons, E. A. Lemke, P. Bork, W. Antonin, J. S. Glavy, K. H. Bui, M. Beck, In situ structural analysis of the human nuclear pore complex. Nature. 526, 140-143 (2015). 
bioRxiv preprint doi: https://doi org/10.1101/2020 07 30.228585. this version posted July 31, 2020. The copyright holder for this preprint (which was not certified by peer review) is the author/funder, who has granted bioRxiv a license to display the preprint in perpetuity. It is made available under aCC-BY-NC-ND 4.0 International license.

Zimmerli, Allegretti et al

545

546

547

548

549

550

551

552

553

554

555

556

557

558

559

560

561

562

563

564

565

566

567

568

569

570

571

572

573

574

575

576

36. J. Kosinski, S. Mosalaganti, A. Von Appen, R. Teimer, A. L. Diguilio, W. Wan, K. H. Bui, W. J. H. Hagen, J. A. G. Briggs, J. S. Glavy, E. Hurt, M. Beck, Molecular architecture of the inner ring scaffold of the human nuclear pore complex. Science (80-. ). 352, 363365 (2016).

37. G. Huang, Y. Zhang, X. Zhu, C. Zeng, Q. Wang, Q. Zhou, Q. Tao, M. Liu, J. Lei, C. Yan, Y. Shi, Structure of the cytoplasmic ring of the Xenopus laevis nuclear pore complex by cryo-electron microscopy single particle analysis. Cell Res. 30, 520-531 (2020).

38. S. Mosalaganti, J. Kosinski, S. Albert, M. Schaffer, D. Strenkert, P. A. Salomé, S. S. Merchant, J. M. Plitzko, W. Baumeister, B. D. Engel, M. Beck, In situ architecture of the algal nuclear pore complex. Nat. Commun. 9, 2361 (2018).

39. H. Asakawa, T. Kojidani, H. J. Yang, C. Ohtsuki, H. Osakada, A. Matsuda, M. Iwamoto, Y. Chikashige, K. Nagao, C. Obuse, Y. Hiraoka, T. Haraguchi, Asymmetrical localization of nup107-160 subcomplex components within the nuclear pore complex in fission yeast. PLoS Genet. 15, 223131 (2019).

40. P. Stelter, R. Kunze, D. Flemming, D. Höpfner, M. Diepholz, P. Philippsen, B. Böttcher, E. Hurt, Molecular basis for the functional interaction of dynein light chain with the nuclear-pore complex. Nat. Cell Biol. 9, 788-796 (2007).

41. S. W. Bai, J. Rouquette, M. Umeda, W. Faigle, D. Loew, S. Sazer, V. Doye, The Fission Yeast Nup107-120 Complex Functionally Interacts with the Small GTPase Ran/Spi1 and Is Required for mRNA Export, Nuclear Pore Distribution, and Proper Cell Division. Mol. Cell. Biol. 24, 6379-6392 (2004).

42. X. Liu, J. M. Mitchell, R. W. Wozniak, G. Blobel, J. Fan, Structural evolution of the membrane-coating module of the nuclear pore complex. Proc. Natl. Acad. Sci. U. S. A. 109, 16498-16503 (2012).

43. S. Bilokapic, T. U. Schwartz, Molecular basis for Nup37 and ELY5/ELYS recruitment to the nuclear pore complex. Proc. Natl. Acad. Sci. U. S. A. 109, 15241-15246 (2012).

44. B. A. Rasala, A. V. Orjalo, Z. Shen, S. Briggs, D. J. Forbes, ELYS is a dual nucleoporin/kinetochore protein required for nuclear pore assembly and proper cell division. Proc. Natl. Acad. Sci. U. S. A. 103, 17801-17806 (2006).

45. S. J. Kim, J. Fernandez-Martinez, I. Nudelman, Y. Shi, W. Zhang, B. Raveh, T. Herricks, B. D. Slaughter, J. A. Hogan, P. Upla, I. E. Chemmama, R. Pellarin, I. Echeverria, M. Shivaraju, A. S. Chaudhury, J. Wang, R. Williams, J. R. Unruh, C. H. Greenberg, E. Y. 
bioRxiv preprint doi: https://doi org/10.1101/2020 07 30.228585. this version posted July 31 2020. The copyright holder for this preprint (which was not certified by peer review) is the author/funder, who has granted bioRxiv a license to display the preprint in perpetuity. It is made available under aCC-BY-NC-ND 4.0 International license.

Zimmerli, Allegretti et al

577

578

579

580

581

582

583

584

585

586

587

588

589

590

591

592

593

594

595

596

597

598

599

600

601

602

603

604

605

606

607

608

Jacobs, Z. Yu, M. J. De La Cruz, R. Mironska, D. L. Stokes, J. D. Aitchison, M. F. Jarrold, J. L. Gerton, S. J. Ludtke, C. W. Akey, B. T. Chait, A. Sali, M. P. Rout, Integrative structure and functional anatomy of a nuclear pore complex. Nature. 555, 475-482 (2018).

46. T. Maimon, N. Elad, I. Dahan, O. Medalia, The human nuclear pore complex as revealed by cryo-electron tomography. Structure. 20, 998-1006 (2012).

47. H. Chug, S. Trakhanov, B. B. Hülsmann, T. Pleiner, D. Görlich, Crystal structure of the metazoan Nup62•Nup58•Nup54 nucleoporin complex. Science (80-. ). 350, 106-110 (2015).

48. R. W. Wozniak, G. Blobel, M. P. Rout, POM152 is an integral protein of the pore membrane domain of the yeast nuclear envelope. J. Cell Biol. 125, 31-42 (1994).

49. P. Upla, S. J. Kim, P. Sampathkumar, K. Dutta, S. M. Cahill, I. E. Chemmama, R. Williams, J. B. Bonanno, W. J. Rice, D. L. Stokes, D. Cowburn, S. C. Almo, A. Sali, M. P. Rout, J. Fernandez-Martinez, Molecular Architecture of the Major Membrane Ring Component of the Nuclear Pore Complex. Structure. 25, 434-445 (2017).

50. A. Elosegui-Artola, I. Andreu, A. E. M. Beedle, A. Lezamiz, M. Uroz, A. J. Kosmalska, R. Oria, J. Z. Kechagia, P. Rico-Lastres, A. L. Le Roux, C. M. Shanahan, X. Trepat, D. Navajas, S. Garcia-Manyes, P. Roca-Cusachs, Force Triggers YAP Nuclear Entry by Regulating Transport across Nuclear Pores. Cell. 171, 1397-1410.e14 (2017).

51. K. Kelley, K. E. Knockenhauer, G. Kabachinski, T. U. Schwartz, Atomic structure of the y complex of the nuclear pore. Nat. Struct. Mol. Biol. 22, 425-431 (2015).

52. K. Thierbach, A. von Appen, M. Thoms, M. Beck, D. Flemming, E. Hurt, Protein Interfaces of the Conserved Nup84 Complex from Chaetomium thermophilum Shown by Crosslinking Mass Spectrometry and Electron Microscopy. Structure. 21, 1672$1682(2013)$.

53. S. Krull, J. Dörries, B. Boysen, S. Reidenbach, L. Magnius, H. Norder, J. Thyberg, V. C. Cordes, Protein Tpr is required for establishing nuclear pore-associated zones of heterochromatin exclusion. EMBO J. 29, 1659-1673 (2010).

54. S. A. Nordeen, D. L. Turman, T. U. Schwartz, bioRxiv, in press, doi:10.1101/2020.06.19.161133.

55. E. Nüske, G. Marini, D. Richter, W. Leng, A. Bogdanova, T. M. Franzmann, G. Pigino, S. Alberti, Biol. Open, in press, doi:10.1242/bio.046391. 
Zimmerli, Allegretti et al

609

610

611

612

613

614

615

616

617

618

619

620

621

622

623

624

625

626

627

628

629

630

631

632

633

634

635

636

637

638

639

640

56. B. R. Parry, I. V. Surovtsev, M. T. Cabeen, C. S. O'Hern, E. R. Dufresne, C. JacobsWagner, The bacterial cytoplasm has glass-like properties and is fluidized by metabolic activity. Cell. 156, 183-194 (2014).

57. B. L. Timney, B. Raveh, R. Mironska, J. M. Trivedi, S. J. Kim, D. Russel, S. R. Wente, A. Sali, M. P. Rout, Simple rules for passive diffusion through the nuclear pore complex. J. Cell Biol. 215 (2016), doi:10.1083/jcb.201601004.

58. S. Frey, D. Görlich, FG/FxFG as well as GLFG repeats form a selective permeability barrier with self-healing properties. EMBO J. 28, 2554-2567 (2009).

59. D. Mohr, S. Frey, T. Fischer, T. Güttler, D. Görlich, Characterisation of the passive permeability barrier of nuclear pore complexes. EMBO J. 28, 2541-2553 (2009).

60. R. Frost, D. Débarre, S. Jana, F. Bano, J. Schünemann, D. Görlich, R. P. Richter, “A method to quantify molecular diffusion within thin solvated polymer films: A case study on films of natively unfolded nucleoporins."

61. S. R. Solmaz, G. Blobel, I. Melcák, Ring cycle for dilating and constricting the nuclear pore. Proc. Natl. Acad. Sci. U. S. A. 110, 5858-5863 (2013).

62. J. Fernandez-Martinez, S. J. Kim, Y. Shi, P. Upla, R. Pellarin, M. Gagnon, I. E. Chemmama, J. Wang, I. Nudelman, W. Zhang, R. Williams, W. J. Rice, D. L. Stokes, D. Zenklusen, B. T. Chait, A. Sali, M. P. Rout, Structure and Function of the Nuclear Pore Complex Cytoplasmic mRNA Export Platform. Cell. 167, 1215-1228.e25 (2016).

63. N. Kellner, J. Schwarz, M. Sturm, J. Fernandez-Martinez, S. Griesel, W. Zhang, B. T. Chait, M. P. Rout, U. Kück, E. Hurt, Developing genetic tools to exploit Chaetomium thermophilum for biochemical analyses of eukaryotic macromolecular assemblies. Sci. Rep. 6, 20937 (2016).

64. H. Amelina, V. Moiseeva, L. C. Collopy, S. R. Pearson, C. A. Armstrong, K. Tomita, Sequential and counter-selectable cassettes for fission yeast. BMC Biotechnol. 16, 76 (2016).

65. J. Bähler, J. Wu, M. S. Longtine, N. G. Shah, A. M. III, A. B. Steever, A. Wach, P. Philippsen, J. R. Pringle, Heterologous modules for efficient and versatile PCR-based gene targeting in Schizosaccharomyces pombe. Yeast. 14, 943-951 (1998).

66. G. Dey, S. Culley, S. A. Curran, R. Henriques, W. Kukulski, B. Baum, Closed mitosis requires local disassembly of the nuclear envelope. bioRxiv, 779769 (2019).

67. A. Vještica, M. Marek, P. Nkosi, L. Merlini, G. Liu, M. Bérard, I. Billault-Chaumartin, S. 
bioRxiv preprint doi: https://doi org/10.1101/2020.0730.228585. this version posted July 31 2020. The copyright holder for this preprint (which was not certified by peer review) is the author/funder, who has granted bioRxiv a license to display the preprint in perpetuity. It is made available under aCC-BY-NC-ND 4.0 International license.

Zimmerli, Allegretti et al

641

642

643

644

645

646

647

648

649

650

651

652

653

654

655

656

657

658

659

660

661

662

663

664

665

666

667

668

669

670

671

672

G. Martin, A toolbox of stable integration vectors in the fission yeast Schizosaccharomyces pombe. J. Cell Sci. 133 (2020), doi:10.1242/jcs.240754.

68. J. Schindelin, I. Arganda-Carreras, E. Frise, V. Kaynig, M. Longair, T. Pietzsch, S. Preibisch, C. Rueden, S. Saalfeld, B. Schmid, J. Y. Tinevez, D. J. White, V. Hartenstein, K. Eliceiri, P. Tomancak, A. Cardona, Fiji: An open-source platform for biological-image analysis. Nat. Methods. 9 (2012), pp. 676-682.

69. S. Berg, D. Kutra, T. Kroeger, C. N. Straehle, B. X. Kausler, C. Haubold, M. Schiegg, J. Ales, T. Beier, M. Rudy, K. Eren, J. I. Cervantes, B. Xu, F. Beuttenmueller, A. Wolny, C. Zhang, U. Koethe, F. A. Hamprecht, A. Kreshuk, ilastik: interactive machine learning for (bio)image analysis. Nat. Methods. 16, 1226-1232 (2019).

70. A. Halavatyi, S. Terjung, in Standard and Super-Resolution Bioimaging Data Analysis (John Wiley \& Sons, Ltd, 2017), pp. 99-141.

71. W. J. H. Hagen, W. Wan, J. A. G. Briggs, Implementation of a cryo-electron tomography tilt-scheme optimized for high resolution subtomogram averaging. J. Struct. Biol. 197, 191-198 (2017).

72. R. Danev, B. Buijsse, M. Khoshouei, J. M. Plitzko, W. Baumeister, Volta potential phase plate for in-focus phase contrast transmission electron microscopy. Proc. Natl. Acad. Sci. U. S. A. 111, 15635-40 (2014).

73. D. N. Mastronarde, S. R. Held, Automated tilt series alignment and tomographic reconstruction in IMOD. J. Struct. Biol. 197, 102-113 (2017).

74. D. N. Mastronarde, Dual-Axis Tomography: An Approach with Alignment Methods That Preserve Resolution. J. Struct. Biol. 120, 343-352 (1997).

75. B. Turoňová, F. K. M. Schur, W. Wan, J. A. G. Briggs, Efficient 3D-CTF correction for cryo-electron tomography using NovaCTF improves subtomogram averaging resolution to 3.4 Å. J. Struct. Biol. 199, 187-195 (2017).

76. B. Turoňová, M. Sikora, C. Schürmann, W. J. H. Hagen, S. Welsch, F. E. C. Blanc, S. von Bülow, M. Gecht, K. Bagola, C. Hörner, G. van Zandbergen, S. Mosalaganti, A. Schwarz, R. Covino, M. D. Mühlebach, G. Hummer, J. K. Locker, M. Beck, bioRxiv, in press, doi:10.1101/2020.06.26.173476.

77. G. Tang, L. Peng, P. R. Baldwin, D. S. Mann, W. Jiang, I. Rees, S. J. Ludtke, EMAN2: An extensible image processing suite for electron microscopy. J. Struct. Biol. 157, 38-46 (2007). 
Zimmerli, Allegretti et al

673

674

675

676

677

678

679

680

681

682

683

684

685

686

687

688

689

690

691

692

693

694

695

696

697

698

699

700

701

702

703

704

78. B. Turoňová, W. J. H. Hagen, M. Obr, S. Mosalaganti, J. W. Beugelink, C. E. Zimmerli, H. G. Kräusslich, M. Beck, Benchmarking tomographic acquisition schemes for highresolution structural biology. Nat. Commun. 11, 1-9 (2020).

79. E. F. Pettersen, T. D. Goddard, C. C. Huang, G. S. Couch, D. M. Greenblatt, E. C. Meng, T. E. Ferrin, UCSF Chimera - A visualization system for exploratory research and analysis. J. Comput. Chem. 25, 1605-1612 (2004).

80. L. Zimmermann, A. Stephens, S. Z. Nam, D. Rau, J. Kübler, M. Lozajic, F. Gabler, J. Söding, A. N. Lupas, V. Alva, A Completely Reimplemented MPI Bioinformatics Toolkit with a New HHpred Server at its Core. J. Mol. Biol. 430, 2237-2243 (2018).

81. N. Guex, M. C. Peitsch, SWISS-MODEL and the Swiss-PdbViewer: An environment for comparative protein modeling. Electrophoresis. 18, 2714-2723 (1997).

82. A. Šali, T. L. Blundell, Comparative protein modelling by satisfaction of spatial restraints. J. Mol. Biol. 234, 779-815 (1993).

83. T. Stuwe, A. R. Correia, D. H. Lin, M. Paduch, V. T. Lu, A. A. Kossiakoff, A. Hoelz, Architecture of the nuclear pore complex coat. Science (80-. ). 347, 1148-1152 (2015).

84. D. H. Lin, T. Stuwe, S. Schilbach, E. J. Rundlet, T. Perriches, G. Mobbs, Y. Fan, K. Thierbach, F. M. Huber, L. N. Collins, A. M. Davenport, Y. E. Jeon, A. Hoelz, Architecture of the symmetric core of the nuclear pore. Science (80-. ). 352, aaf1015aaf1015 (2016).

85. C. S. Weirich, J. P. Erzberger, J. M. Berger, K. Weis, The N-terminal domain of Nup159 forms a $\beta$-propeller that functions in mRNA export by tethering the helicase Dbp5 to the nuclear pore. Mol. Cell. 16, 749-760 (2004).

86. K. Yoshida, H. S. Seo, E. W. Debler, G. Blobel, A. Hoelz, Structural and functional analysis of an essential nucleoporin heterotrimer on the cytoplasmic face of the nuclear pore complex. Proc. Natl. Acad. Sci. U. S. A. 108, 16571-16576 (2011).

87. K. Strimmer, fdrtool: A versatile R package for estimating local and tail area-based false discovery rates. Bioinformatics. 24, 1461-1462 (2008).

88. Y. Benjamini, Y. Hochberg, Controlling the false discovery rate: a practical and powerful approach to multiple testing. J. R. Stat. Soc. Ser. B. 57, 289-300 (1995).

89. T. D. Goddard, C. C. Huang, E. C. Meng, E. F. Pettersen, G. S. Couch, J. H. Morris, T. E. Ferrin, UCSF ChimeraX: Meeting modern challenges in visualization and analysis. 
Zimmerli, Allegretti et al

705

706

707

708

709

710

711

712

713

714

715

716

717

718

719

720

Protein Sci. 27, 14-25 (2018).

90. B. Webb, S. Viswanath, M. Bonomi, R. Pellarin, C. H. Greenberg, D. Saltzberg, A. Sali, Integrative structure modeling with the Integrative Modeling Platform. Protein Sci. 27, 245-258 (2018).

91. D. Saltzberg, C. H. Greenberg, S. Viswanath, I. Chemmama, B. Webb, R. Pellarin, I. Echeverria, A. Sali, in Methods in Molecular Biology (Humana Press Inc., 2019; https://pubmed.ncbi.nlm.nih.gov/31396911/), vol. 2022, pp. 353-377.

92. G. Drin, J. F. Casella, R. Gautier, T. Boehmer, T. U. Schwartz, B. Antonny, A general amphipathic $\alpha$-helical motif for sensing membrane curvature. Nat. Struct. Mol. Biol. 14, 138-146 (2007).

93. H. Asakawa, H.-J. Yang, T. G. Yamamoto, C. Ohtsuki, Y. Chikashige, K. Sakata-Sogawa, M. Tokunaga, M. Iwamoto, Y. Hiraoka, T. Haraguchi, Characterization of nuclear pore complex components in fission yeast Schizosaccharomyces pombe. Nucleus. 5, 149162 (2014). 